\title{
O PAPEL DO SUPREMO TRIBUNAL FEDERAL NO IMPEACHMENT DA PRESIDENTE DILMA ROUSSEFF
}

THE ROLE OF BRAZILIAN SUPREME COURT IN PRESIDENT DILMA ROUSSEFF'S IMPEACHMENT

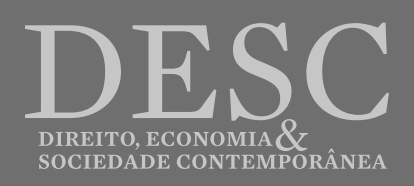




\title{
O PAPEL DO SUPREMO TRIBUNAL FEDERAL NO IMPEACHMENT DA PRESIDENTE DILMA ROUSSEFF ${ }^{1}$
}

\author{
THE ROLE OF BRAZILIAN SUPREME COURT IN \\ PRESIDENT DILMA ROUSSEFF'S IMPEACHMENT
}

\author{
ELOÍSA MACHADO DE ALMEIDA \\ Escola de Direito da Fundação Getúlio Vargas de São Paulo FGV Direito SP \\ eloisa.machado@fgv.br \\ lattes.cnpq.br/1525448483917339 \\ orcid.org/0000-0003-1617-1739
}

\begin{abstract}
Resumo: Este artigo tem por objetivo analisar o papel desempenhado pelo Supremo Tribunal Federal no processo de impeachment da Presidente Dilma Rousseff. Em sua primeira parte, este artigo apresenta uma breve descrição do contexto no qual se deu o processo de impeachment, com o objetivo de propor que ele seja analisado concomitantemente às principais decisões do Supremo Tribunal Federal na Operação Lava Jato. A segunda parte do artigo apresenta os contornos constitucionais do impeachment, sua excepcionalidade, os crimes de responsabilidade e a regulamentação legal, enquanto parâmetros de constitucionalidade que deveriam informar a atuação do tribunal. Por fim, na terceira parte são analisadas as decisões judiciais referentes ao impeachment e à Operação Lava Jato que indicam um papel proeminente do Supremo Tribunal Federal no desenrolar dos acontecimentos.
\end{abstract}

Palavras-chave: impeachment; Supremo Tribunal Federal; Operação Lava Jato; Dilma Rousseff.

\begin{abstract}
This article intents to analyze the role played by the Brazilian Federal Supreme Court in the impeachment process of President Dilma Rousseff. First, this article presents a brief description of the context in which the impeachment process took place, in order to analyze it concurrently with the main decisions of the Federal Supreme Court in Operation Car Wash ("Operação Lava Jato"). The second part of the article presents the constitutional outlines of impeachment, its exceptionality, connected crimes and legal regulation, as parameters of constitutionality that should inform the court's performance. Finally, the third part reviews the court decisions regarding impeachment and "Operation Car Wash" which indicate a prominent role of the Federal Supreme Court in the course of these events.
\end{abstract}

Keywords: impeachment; Brazilian Supreme Court; Operation Car Wash; Dilma Rousseff.

\footnotetext{
1 Artigo preparado e apresentado no 2017 Congress of the Latin American Studies Association, Lima, Perú, Abril 20 - May 1, 2017.
} 


\section{Contexto anterior ao impeachment: eleições presidenciais de 2014 e primeiro ano de mandato presidencial de Dilma Rousseff}

Para compreender o processo de impeachment de Dilma Rousseff, é preciso retornar às eleições presidenciais de 2014. Marcada por campanhas agressivas e acirramento entre os projetos do PT e do PSDB, foi a eleição com menor diferença de votos da história brasileira: Dilma Rousseff (PT) obteve 51,64\% dos votos válidos e o segundo colocado, Aécio Neves (PSDB) obteve $48,36 \%^{2}$ (TSE, 2014).

Ainda em 2014, na primeira semana após o resultado das eleições - o segundo turno das eleições presidenciais ocorreu em 25 de outubro de 2014, sendo os resultados divulgados pelo Tribunal Superior Eleitoral no mesmo dia - já se falava da necessidade de impeachment da Presidente Dilma Rousseff. Essa ideia, que contava com a adesão de poucos movimentos de ultradireita $^{3}$, toma força com a resistência da oposição em aceitar o resultado das eleições, que chega até a formalizar um pedido de auditoria dos votos ${ }^{4}$. Esses grupos e a oposição passam a alimentar a ideia de impeachment mesmo antes do início do novo mandato. A resistência da oposição em se assumir como vencida nas urnas e a movimentação de pequenos grupos torna a ideia de impeachment de Dilma Rousseff uma constante durante o final de seu mandato de 2014.

No começo do novo mandato, já em 2015, a oposição encomenda a juristas um parecer sobre a possibilidade de se realizar o impeachment, sendo que a principal controvérsia jurídica naquele momento era a possibilidade de cassação por atos cometidos em mandato anterior ou mesmo antes disso ${ }^{5}$. Aos poucos, a ideia de impeachment se torna mais comum e os grandes veículos de comunicação do país passam a cogitar sua possibilidade. São protocolados vários pedidos $^{6}$ de impeachment para o Presidente da Câmara dos Deputados, baseados, até então, em motivos difusos associados à Operação Lava Jato, como as operações comerciais envolvendo

2 Segundo os dados oficiais divulgados pelo Tribunal Superior Eleitoral, Dilma Rousseff, eleita, obteve 54.501.118 votos e Aécio Neves obteve 51.041.155 votos, uma diferença de pouco mais de 3 milhões de votos (TSE, 2014).

3 Se os protestos de 2013 podem ser descritos como a emergência de novas reivindicações de esquerda, com demandas de ampliação e consolidação de um Estado Social, os movimentos de 2015 em prol do impeachment, ainda que não em sua totalidade, ficaram marcados por reivindicações de apoio a militares, de volta de regime militar, de nacionalismo e intolerância. Não há estudos brasileiros que indiquem a relação entre movimentos de insatisfação popular de 2013 com a emergência e fortalecimento de uma nova direita em 2015, nem o quanto isso será capitalizado pelos partidos políticos, mas essa hipótese foi trabalhada por Rydgren (2007) no contexto europeu: "Finally, one strand within the literature on the new radical right claims that the growing political alienation and discontent in Western European countries have created an audience receptive to antisystem and antiestablishment messages, and thus provided an opportunity for the new radical right wing parties to mobilize protest voters" (RYDGREN, 2007, p. 251).

4 Pedido feito pelo Partido da Social Democracia Brasileira-PSDB em 30 de outubro de 2015. TSE, Processo 185520.2014.600.0000. O TSE autorizou a liberação das informações das urnas eletrônicas e o PSDB fez uma auditoria particular, cuja conclusão foi a impossibilidade de realizar uma plena auditagem, não havendo conclusão sobre a existência de fraude eleitoral.

5 A questão jurídica que mobilizou o debate sobre o impeachment se concentrou na possibilidade de se proceder a um impeachment por ato praticado em mandato anterior. De um lado, foi debatida a tese de que a emenda constitucional que permitiu reeleições permitiria, também, a continuidade do nexo de responsabilização para um segundo mandato; de outro, a tese de que novas eleições, ainda que reelejam o mesmo candidato, inaugurariam um novo e diferente mandato, impedindo a responsabilização por atos anteriores.

6 O pedido de impeachment pode ser feito por qualquer cidadão brasileiro. A Câmara dos Deputados divulgou que, desde 1990, foram protocolados 132 pedidos de impeachment contra os presidentes brasileiros: Collor (1990-92): 29; Itamar (1992-94); FHC - $1^{\circ}$ mandato: (1995-98): 1; FHC - $2^{\circ}$ mandato (1999-2002): 16; Lula - $1^{\circ}$ mandato (2003-06): 25; Lula - $2^{\circ}$ mandato (2007-10): 9; Dilma - $1^{\circ}$ mandato (2011-14): 14; Dilma - $2^{\circ}$ mandato (2015): 34 . 
Pasadena, e a ocupação, por Dilma, do cargo de Presidente do Conselho de Administração da Petrobrás entre 2003 e 2010. As denúncias e o clamor público por impeachment aumentam na mesma medida em que a Operação Lava Jato atinge pessoas próximas à Presidente, ao PT e de sua base aliada, cujo ápice se dá em março de 2015, quando o Procurador Geral da República, Rodrigo Janot, solicita ao Supremo Tribunal Federal a autorização para investigar uma série de parlamentares ${ }^{7}$.

A oposição encomenda, por fim, um pedido de impeachment que congrega acusações de prática de crime de responsabilidade consistem em atos contra a probidade na administração, contra a lei orçamentária e o cumprimento de leis e decisões judiciais (art. 85, V, VI e VII da Constituição) $)^{8}$. O pedido é protocolado em $1^{\circ}$ de setembro de 2015 , sendo emendado depois de suas semanas. A partir de então, paira sobre a Presidente a ameaça real de impeachment, cuja competência para instauração é determinada, pela interpretação da Constituição, unicamente ao Presidente da Câmara dos Deputados, Eduardo Cunha9 .

Assim, ganha força o pedido de impeachment e, com ele, ganha força o Presidente da Câmara dos Deputados, Eduardo Cunha. Então investigado pelo Supremo Tribunal Federal por suposta participação na Operação Lava Jato (inquérito instaurado em março de 2015), Eduardo Cunha passa, pelos mesmos fatos, a ser processado pela Comissão de Ética da Câmara dos Deputados, denúncia apresentada em outubro de 2015. A integridade do mandato de Eduardo Cunha passa a estar vinculada, assim, a negociações com o futuro do processo de impeachment; a manutenção do mandado de Dilma passa a depender de Eduardo Cunha e dos desdobramentos da Operação Lava Jato.

Neste breve relato, fica assentado que o impeachment de Dilma Rousseff foi, sobretudo, uma medida articulada em resposta à sua vitória nas eleições. Não se trata, assim, de um processo de impeachment baseado em um fato determinado ou em um escândalo em particular. Da mesma forma, mostra que é impossível analisar o processo de impeachment sem relacioná-lo à Operação Lava Jato. Trata-se de um contínuo processo de desgaste, agravado por uma crise política sistêmica gerada pelo alcance da Operação Lava Jato, atingindo não só a Presidência da República, como também a oposição, a Câmara dos Deputados e o Senado Federal.

Por isso, mesmo que o objetivo desse artigo seja analisar o papel que o Supremo Tribunal

\footnotetext{
7 Na primeira leva de inquéritos, são 47 parlamentares, de diferentes partidos, cuja investigação foi solicitada ao STF. A segunda envolveu o pedido de abertura de mais de 83 inquéritos. A Procuradoria Geral da República mantém um sítio eletrônico com as informações sobre a Operação Lava Jato (lavajato.mpf.mp.br).

8 A denúncia de impeachment que teve andamento foi assinada por Hélio Bicudo, Miguel Reale Junior e Janaina Paschoal, estes dois últimos contratados pelo PSDB, como afirmaram em depoimentos no Senado Federal.

9 O Supremo Tribunal Federal estabeleceu como precedente, no julgamento do impeachment de Fernando Collor, que a “apresentação da denúncia à Câmara dos Deputados: competência do presidente desta para o exame liminar da idoneidade da denúncia popular, que não se reduz à verificação das formalidades extrínsecas e da legitimidade de denunciantes e denunciados, mas se pode estender (...) à rejeição imediata da acusação patentemente inepta ou despida de justa causa, sujeitando-se ao controle do Plenário da Casa, mediante recurso (...)". MS 20.941-DF, Sepúlveda Pertence, DJ de 31-8-1992.
} 
Federal desempenhou ao longo do processo de impeachment da Presidente Dilma Rousseff, serão analisadas não só as decisões judiciais diretamente relacionadas ao processo de impeachment de Dilma Rousseff, como também as principais decisões judiciais decorrentes da Operação Lava Jato que foram capazes de interferir no curso do processo de impeachment.

Esse artigo apresenta, assim, três teses fundamentais. A primeira é de que o impeachment pode ter sua constitucionalidade analisada não apenas pelo viés formal processual, mas também no seu mérito, ou seja, na caracterização, ou não de crime de responsabilidade. Esse ponto compartilha a ideia de que a própria Constituição estabelece parâmetros capazes de orientar a constitucionalidade de um processo de impeachment.

A segunda tese é a de que o processo de impeachment deve ser analisado concomitante e paralelamente aos desdobramentos judiciais da Operação Lava Jato. Apenas analisando as decisões emitidas pelo Supremo Tribunal Federal em ambas as áreas é possível compreender o ritmo dos acontecimentos.

Por fim, a terceira tese desse artigo afirma que o Supremo Tribunal Federal desempenhou um papel significativo no desenrolar do processo de impeachment e da crise política no país. Isso, por sua vez, tornou mais desgastadas os poderes Executivo e Legislativo, expostos no centro da crise. Se em uma democracia essas razões bastariam para expor o problemático papel do tribunal, o cenário fica ainda mais grave ao se considerar que o Judiciário foi, em si, um agente de desestabilização política e institucional no Brasil.

\section{Impeachment na Constituição de 1988}

O impeachment está previsto expressamente na Constituição de 1988, nos artigos 85 e 86. Sua previsão não é novidade, já que as Constituições anteriores, de 1946 e de 1967, previam as consequências institucionais para a hipótese de impedimento do Presidente da República ${ }^{10}$. Porém, se a previsão constitucional do impeachment não é inaugurada pela Constituição de 1988, o são as suas condições e delineamentos. Os artigos 85 e 86 da Constituição não só preveem a possibilidade de impeachment como definem as hipóteses nas quais ele será possível, além de indicar os espaços institucionais nos quais deve se desenrolar tal processo.

Trata-se, inegavelmente, de um procedimento jurídico-político: os contornos são jurídicos e regulados pelo direito; porém o julgamento é realizado pelas instâncias políticas.

A interpretação mais comum que se fez desse instrumento híbrido é o de que caberá às instâncias políticas um amplo poder no processo de impeachment, não só enquanto espaço de julgamento, mas também de definição do que seriam os crimes de responsabilidade. Nesta leitura, amparada por Brossard (1992), Temer (1994) e Bastos (1990), Câmara dos Deputados

10 Artigo 79 da Constituição de 1946 e artigos 80 da Constituição de 1967. 
e Senado Federal têm ampla margem de discricionariedade para decidir o que é crime de responsabilidade, sendo vedado ao Judiciário interferir no processo, exceto para garantir o devido processo legal e a ampla defesa. Por se tratar de julgamento político, as razões que podem levar um Presidente à perda de seu mandato também são políticas.

Brossard, ao analisar o impeachment na Constituição de 1988, defende que, apesar do julgamento político não prescindir dos limites jurídicos, poderia ser mais amplo que este: “ (...) o impeachment tem feição política, não se origina senão de causas políticas, objetiva resultados políticos, é instaurado sob considerações de ordem política e julgado segundo critérios políticos julgamento que não exclui, antes supõe, é óbvio, a adoção de critérios jurídicos” (BROSSARD, 1992, p. 65).

Essa posição, que foi acolhida pelo Supremo Tribunal Federal no julgamento do processo de impeachment de Fernando Collor ${ }^{11}$, assentou o entendimento de que o processo de impeachment é conduzido pelas instâncias políticas, sem interferência do poder Judiciário, a quem caberia apenas assegurar que o acusado tenha a possibilidade de exercer o seu direito à ampla defesa. Essa mesma posição prevaleceu no julgamento do processo de impeachment de Dilma Rousseff.

Esse artigo contesta esse entendimento por duas razões. A primeira delas é por defender que a Constituição oferece parâmetros que permitem o controle de constitucionalidade do impeachment, notadamente da definição de crime de responsabilidade, tanto material como formalmente.

A segunda razão reside no fato de que a limitação da atuação do Legislativo no impeachment, circunscrita à deflagração do processo apenas se presentes atos que correspondem à definição estrita de crimes de responsabilidade, é um mecanismo constitucional de freios e contrapesos que protege o Executivo - e o mandato obtido em eleições - de uma ingerência abusiva, ou auto-interessada (ELSTER, 2009, p. 210-211), do Legislativo (SUNSTEIN, 2001, p. 117).

\subsection{Crime de responsabilidade: aspectos constitucionais}

O impeachment, pelo regime estabelecido na Constituição de 1988, só pode ocorrer nas hipóteses de cometimento de crime de responsabilidade, definidos como atos do Presidente da República que atentem contra a Constituição Federal, especialmente contra a existência da União, o livre exercício dos poderes Legislativo e Judiciário, do Ministério Público e dos poderes das unidades federadas, o exercício de direitos políticos, individuais e sociais, a segurança interna do país, a probidade da administração, a lei orçamentária ou que atentem contra, ainda contra o cumprimento de leis e decisões judiciais no país.

11 Questões discutidas no âmbito de três mandados de segurança: MS 21.689; MS 23.885; MS 21.564. 
Essas hipóteses trazem a descrição de graves atos que podem ser praticados pelo Presidente da República, mas sua indeterminação faz com que praticamente qualquer ato possa ser enquadrado como crime de responsabilidade. Por exemplo, qualquer decreto produzido pelo Presidente ou que não tenha sido por este expressamente vetada, que seja inconstitucional (inclusive com posterior declaração pelo Supremo Tribunal Federal) poderia, em tese, estar circunscrito na hipótese de atendado contra a Constituição. Isso não parece razoável, já que o impeachment é, nos sistemas presidencialistas, uma medida bastante gravosa, qual seja, a perda de um mandato conferido por eleição direta.

Afinal, não se trata de um processo que traz consequências apenas para o Presidente da República, mas para todos os eleitores. O mandato eleitoral e o vínculo de representatividade obtido mediante eleições diretas são protegidos pela Constituição. A soberania popular é o que legitima o poder político (art. $1^{\circ}$, parágrafo único, $\mathrm{CF} / 88$ ), com a previsão de que o poder emana do povo que o exerce por meio de representantes eleitos ou diretamente, sendo poucas as hipóteses nas quais o mandato pode ser impugnado (artigos 14 e $15 \mathrm{CF} / 88$ ).

A desconstrução desse vínculo de representatividade, através da interrupção do mandato, dá-se nas hipóteses em que a própria competição eleitoral foi frustrada (DOWNS, 1999), como em corrupção, fraude ou abuso de poder econômico; por impugnação de mandato, ou ainda nas hipóteses em que o mandatário perde seus direitos políticos ${ }^{12}$. Para o cargo de Presidente da República essas hipóteses são ainda mais restritas, já que a Constituição lhe garante imunidade, durante a vigência de seu mandato, por atos estranhos às suas funções. Disso decorre que o Presidente da República poderá perder seu mandato na hipótese de condenação por crime de responsabilidade; por sentença penal transitada em julgado por prática de crime comum relacionado às suas funções, por incapacidade civil absoluta.

Se a Constituição estabelece que um Presidente da República só pode ser processado por crimes comuns se estes forem praticados com o uso do cargo e do mandato, requerendo-se ainda, para tanto, a autorização da Câmara dos Deputados, a perda do mandato não é a pena em si, mas pode vir a ser uma consequência da pena criminal. Mesmo assim, restaria a dúvida sobre os efeitos da condenação criminal, isto é, se a perda de mandato seria uma consequência automática dessa ${ }^{13}$. Já o crime de responsabilidade busca afetar diretamente o vínculo de representatividade, tendo como único objetivo a perda do mandato. Assim, o impeachment é a

12 O artigo 15 estabelece cinco hipóteses de perda dos direitos políticos, quais sejam, o cancelamento da naturalização, a incapacidade civil absoluta, a condenação criminal transita em julgado, enquanto durarem seus efeitos, a recusa a cumprir obrigação a todos imposta ou improbidade administrativa. Para Presidente da República, não se aplicam as hipóteses de perda de mandato por cancelamento de naturalização, já que o cargo de Presidente da República só pode ser exercido por brasileiro nato $\left(\operatorname{art} .12, \S 3^{\circ}\right)$ e não está sujeito ao regime específico de responsabilização por improbidade administrativa (art. 37, §4 e Lei 8.429/92), dado o regime específico de responsabilização constitucional mediante apuração de crime de responsabilidade previsto nos artigos 85 e 86 da Constituição. Isso, ao menos, foi o decidido pelo STF na AC 2790.

13 Isso porque, para parlamentares, a condenação criminal transitada em julgado não acarreta, automaticamente, a perda de mandato, devendo a respectiva casa do Congresso Nacional deliberar sobre a perda de mandato, por maioria absoluta (art. 55, $\S 2^{\circ}, \mathrm{CF} / 88$ ). 
consequência mais grave que pode ocorrer nessa relação entre eleitor e mandatário.

Por isso, crimes de responsabilidade pressupõem uma anormalidade, atos de uma gravidade extraordinária, que representem uma real ruptura da confiança depositada, mediante voto, no mandatário do cargo de Presidente da República. Diferentemente do sistema estadunidense ${ }^{14}$, no qual não há a previsão expressa das hipóteses de crimes de responsabilidade, o sistema brasileiro aponta um rol de infrações consideradas graves o suficiente a ponto de serem consideradas como tais.

Além da orientação sobre a sua gravidade e excepcionalidade, a Constituição estabelece a forma pela qual deve se dar a definição dos crimes de responsabilidade. No parágrafo único do artigo 85, a Constituição determina que os crimes de responsabilidade devem ser definidos por lei especial.

Disso decorrem duas conclusões: a primeira delas é a de que os crimes de responsabilidade devem representar atos de extrema gravidade; não são apenas crimes comuns, para os quais se tem um tratamento distinto e consequências diversas. A segunda delas é a de que, não obstante não serem crimes comuns, os crimes de responsabilidade também devem ser definidos, ou seja, deve haver uma hipótese clara de incidência da norma no caso concreto, uma tipificação.

A lei deve definir, sem margem para dúvidas, quais atos correspondem a crimes de responsabilidade, delimitando, objetivamente ${ }^{15}$, as hipóteses nas quais se dará a perda do mandato do Presidente da República.

Assim, a Constituição estabelece ao menos dois parâmetros para os crimes de responsabilidade: um material, a indicar que apenas atos de extrema gravidade podem dar ensejo à perda de mandato de Presidente da República e outro formal, de que tais atos devem ser descritos com precisão em lei especial. Sendo tais parâmetros constitucionais, há possibilidade de realizar o controle de constitucionalidade.

\footnotetext{
Mesmo não havendo igual e expressa previsão constitucional para as condenações criminais de Presidente da República, há uma defesa razoável de que o objetivo constitucional de defesa do mandato eletivo exigiria, para os cargos do Executivo, igual cautela. No julgamento da AP 470 (o caso conhecido como Mensalão), os ministros debateram sobre os efeitos da condenação criminal sobre os mandatos parlamentares: por maioria ( 5 votos a 4 ), decidiram que os efeitos da condenação sobre o mandato são automáticos. Porém, de maneira tangencial, ao analisar a hipótese de perda de mandato de Presidente da República por condenação criminal transitada em julgado, alguns dos ministros indicaram que o rito de perda de mandato de Presidente é aquele definido pelos artigos 85 e 86 da Constituição Federal, mediante, portanto, instauração de processo de impeachment. Por exemplo: "A regra da cassação imediata dos mandatos, no entanto, aplica-se, por inteiro e de imediato, aos vereadores, bem como aos prefeitos, governadores e ao próprio Presidente da República, por força do que se contém no referido art. 15, III, da Constituição (...) Vale lembrar, contudo, por oportuno, que a perda do mandato do Presidente da República regula-se por um procedimento complexo, regido pelo disposto nos artes. 85 e 86 de nossa Lei Maior. Ou seja, depende da observância de um rito especial, caracterizado por um maior cuidado, por tratar-se do afastamento do Chefe de Estado e de Governo do País" (STF, AP 470, Voto ministro Revisor, Ricardo Lewandowski).
}

14 Diferentemente do sistema estadunidense, no qual não há a previsão expressa das hipóteses de crimes de responsabilidade, o sistema brasileiro aponta um rol de infrações consideradas graves o suficiente a ponto de caracterizarem-se como tais. Mesmo assim, em um espaço de cognição bastante amplo, o impeachment de um presidente no sistema estadunidense seria constitucional apenas nas hipóteses de abusos de autoridade em larga escala, como alerta Sunstein (2011, p. 116), dando como exemplo a inconstitucionalidade de um pedido de impeachment contra Clinton por assédio sexual.

15 Na Reclamação 2138, o Supremo Tribunal Federal apontou que a "interpretação extensiva, entretanto, não seria possível, por isso que, tratando-se de crime, seja crime comum, ou crime de responsabilidade, observa-se a tipificação cerrada, sem possibilidade de interpretação extensiva ou analógica" (STF, Rcl 2138, ministro relator Carlos Velloso). 
Além disso, a Constituição também oferece controles institucionais para que a perda de mandato de Presidente da República seja cercada de cautelas.

\subsection{Impeachment e o papel do Legislativo}

Sunstein (2001) alerta para o fato que, quanto mais simples são os motivos pelos quais se permite o impeachment de um Presidente da República (em uma gradação que vai de uma mera violação da lei, passa por cometimento de crimes, até o massivo abuso de poder), mais próximo se estará de um sistema parlamentarista, nos quais um voto de desconfiança seria o suficiente para a troca do comando do Executivo. Entretanto, em democracias profundamente marcadas pelo presidencialismo, critérios mais rígidos precisariam ser impostos às possibilidades de impeachment, evitando que se torne um tipo de arma política capaz de perverter até a competição eleitoral. Isso causaria uma perversa dependência do Executivo para com o Legislativo, em contradição com a autonomia que o voto popular lhe confere, mostrando-se inconstitucional.

Ao fazer essas considerações, o autor esclarece que o impeachment, nos Estados Unidos, tem sido usado apenas como último recurso em uma longa trajetória de presidentes, o que mostra, de certa forma, o relevante papel que a Constituição americana exerce na preservação da democracia.

Já no Brasil, não podemos tratar o impeachment como uma exceção: dos quatro Presidentes da República eleitos (e reeleitos) desde 1988, dois sofreram impeachment. Isso parece revelar, ao menos em um primeiro momento, que há uma relação de dependência maior entre Executivo e Legislativo ou mecanismos de proteção do mandato falhos e insuficientes, ou ambos.

O processo de perda de mandato estabelecido pela Constituição prevê a participação das duas casas do Congresso Nacional. À Câmara dos Deputados cabe a autorização, ou não, para o processamento da denúncia; ao Senado Federal cabe a análise de sua admissibilidade, o juízo de pronúncia e o efetivo julgamento do Presidente da República. São fases complexas e combinadas que exigem maiorias simples e qualificadas de $2 / 3$ de ambas as casas para que o processo tenha seguimento. É um processo longo e exige, além de um comprometimento por um tempo razoável com o processo de impeachment, uma ampla maioria. São elementos que atuam como obstáculos a questões momentâneas ou impulsos que poderiam gerar a cassação de mandato presidencial.

Sunstein, analisando a constitucionalidade do impeachment no sistema estadunidense, explica a exigência de um forte consenso bipartidário sobre a sua adequação e necessidade, evitando que um "efeito manada" de grupos pequenos ou estreitas maiorias possam criar tamanha instabilidade institucional (SUNSTEIN, 2001, p. 118), como uma forma de freios e contrapesos ao sistema democrático. 
De certa forma, o processo de impeachment previsto na Constituição brasileira impõe também a necessidade de um amplo consenso partidário, mas com características e consequências diversas quando analisadas sob o prisma de um presidencialismo de coalizão (ABRANCHES, 1988). Se em sistemas bipartidários o consenso entorno do processo de impeachment precisa ser amplo e sólido, no sistema pluripartidário ele depende de uma ampla coalizão entre os partidos. Porém, com a atual fragmentação da configuração partidária, os partidos políticos pequenos desempenham papel decisivo ${ }^{16}$, como ficou demonstrado, ao final, no processo de impeachment. Com isso, mesmo que seja possível atingir a maioria, não se pode afirmar que ela seja consistente, ou seja, é possível a formação de uma ampla maioria, porém de ocasião, especialmente na Câmara dos Deputados.

Nesse cenário, uma vez fragilizada a coalizão que ampara o Presidente ${ }^{17}$, torna-se viável o impeachment, sobretudo se fica delegada ao Legislativo a definição do que vem a ser o crime de responsabilidade, na interpretação de que há flexibilidade na sua tipificação, por se tratar de um processo político. Assim, haveria uma grande aproximação com o voto de desconfiança do sistema parlamentarista, no qual a crise política e a perda de governabilidade podem vir a acarretar a drástica medida de perda do mandato presidencial.

Sob este viés, a deflagração de um processo de impeachment pelo Legislativo, sem a exigência de que atos graves cometidos pelo Presidente da República, acarreta um desequilíbrio na relação entre os poderes, sobretudo quando o Judiciário, no caso o Supremo Tribunal Federal, mantém uma posição deferente aos amplos poderes do Legislativo. Por isso, a rigidez na definição dos crimes de responsabilidade mostra-se uma peça central no processo de impeachment.

\subsection{Crime de responsabilidade no impeachment de Dilma Rousseff}

Dilma Rousseff foi acusada, e posteriormente condenada, de praticar crime de responsabilidade consistente em atentado contra a lei orçamentária (art. 85, VI, CF/88), mediante a abertura de créditos suplementares por Decreto Presidencial, sem a prévia autorização do Congresso Nacional e contratação ilegal de operações de crédito, as chamadas pedaladas fiscais.

Tais condutas estariam também descritas na Lei 1.079/50, na redação que lhe foi dada pela lei dos crimes fiscais, Lei 10.020/2000:

\footnotetext{
“Art. 10. São crimes de responsabilidade contra a lei orçamentária:

(...)

4. infringir, patentemente, e de qualquer modo, dispositivo da lei orçamentária;

6. ordenar ou autorizar a abertura de crédito em desacordo com os limites estabelecidos pelo Senado Federal, sem fundamento na lei orçamentária ou na de crédito adicional ou com inobservância de prescrição legal;
}

\footnotetext{
16 Usando como exemplo o quórum do impeachment na Câmara dos Deputados, temos que 6 partidos concentram 2/3 dos votos e 16 partidos políticos detém o $1 / 3$ restante. O crescimento constante do número de partidos política é uma das hipóteses explicativas para os problemas de governabilidade no presidencialismo de coalizão.

17 Para entender melhor o presidencialismo brasileiro, ver em Abranches (1998) e Figueiredo e Limongi (1998) e Limongi (2006).
} 
7. deixar de promover ou de ordenar na forma da lei, o cancelamento, a amortização ou a constituição de reserva para anular os efeitos de operação de crédito realizada com inobservância de limite, condição ou montante estabelecido em lei.

Art. 11. São crimes contra a guarda e legal emprego dos dinheiros públicos:

(...)

2 - Abrir crédito sem fundamento em lei ou sem as formalidades legais;

3 - Contrair empréstimo, emitir moeda corrente ou apólices, ou efetuar operação de crédito sem autorização legal".

A maior dificuldade do processo de impeachment de Dilma Rousseff foi a construção da tipificação de suas condutas como crime de responsabilidade, sobretudo pela reiteração dos atos ao longo dos anos e aceitação pelos órgãos de controle, como o Tribunal de Contas da União e o próprio Congresso Nacional.

Por exemplo, a acusação de que havia sido contraído empréstimo estava baseada no atraso dos repasses de valores a bancos públicos, chamadas de pedaladas fiscais. Para a acusação, isso seria o equivalente a empréstimo; para a defesa, seria apenas um atraso em contratos, mas não um empréstimo autônomo. O Tribunal de Contas da União (TCU) ${ }^{18}$, ao analisar as contas presidenciais, verificara a existência dessa manobra desde a presidência de Fernando Henrique Cardoso, classificando em seus relatórios, ao longo dos anos, como inconsistências na prestação de contas, mas aprovando-as. Em 2014, o Tribunal de Contas da União altera seu entendimento ${ }^{19}$ e rejeita as contas presidenciais, sobretudo pelo montante dos valores devidos aos bancos públicos. Com isso, caracteriza-se como crime menos o ato em si e mais o volume da transação, dando espaço para questionamentos sobre oportunismo do TCU e politização da decisão.

No mesmo sentido, a acusação de edição de créditos suplementares sem autorização do Congresso Nacional foi bastante criticada pois não haveria aumento de despesa e sim a realocação de recursos de lei orçamentária já aprovada pelo Congresso Nacional, o que estaria de acordo com os requisitos constitucionais previstos no artigo 167, que vedaria apenas a "abertura de crédito suplementar ou especial sem prévia autorização legislativa e sem indicação dos recursos correspondentes". Isso fez com que a caracterização, ou não, desses atos como crimes de responsabilidade fossem o foco de todo o processo de impeachment.

\footnotetext{
18 Tribunal de Contas da União é órgão auxiliar do Poder Legislativo na análise da prestação de contas do governo federal, conforme artigo 71 da Constituição Federal de 1988.

19 Trecho do parecer prévio do Tribunal de Contas da União, encaminhado ao Congresso Nacional: “ O Tribunal de Contas da União é de parecer que as Contas atinentes ao exercício financeiro de 2014, apresentadas pela Excelentíssima Senhora Presidente da República, Dilma Vana Rousseff, exceto pelos possíveis efeitos dos achados de auditoria referentes às demonstrações contábeis da União, consignados no relatório, representam adequadamente as posições financeira, orçamentária, contábil e patrimonial, em 31 de dezembro de 2014; contudo, devido à relevância dos efeitos das irregularidades relacionadas à execução dos orçamentos, não elididas pelas contrarrazões apresentadas por Sua Excelência, não houve observância plena aos princípios constitucionais e legais que regem a administração pública federal, às normas constitucionais, legais e regulamentares na execução dos orçamentos da União e nas demais operações realizadas com recursos públicos federais, conforme estabelece a lei orçamentária anual, razão pela qual as Contas não estão em condições de serem aprovadas, recomendando-se a sua rejeição pelo Congresso Nacional”. (TCU, TC 005.335/2015-9).
} 


\section{Papel do Supremo Tribunal Federal no impeachment de Dilma Rousseff}

Como já mencionado, o Supremo Tribunal Federal foi instado a se manifestar sobre o processo de impeachment variadas vezes, provocado ora pelos apoiadores do impeachment, ora por seus opositores, ora pela defesa da Presidente Dilma Rousseff. De forma concomitante, o mesmo tribunal analisou uma série de medidas judiciais relativas à Operação Lava Jato.

Ainda que formalmente distintos, já que o impeachment não foi instaurado e processado por atos da Operação Lava Jato (mas por violações à lei orçamentária e à probidade administrativa), ambos estiveram conectados no tempo e se influenciaram mutuamente, num tipo de contaminação cruzada, onde as razões de um processo influenciam indireta e extra processualmente outro ${ }^{20}$.

\subsection{Os processos judicias relativos ao impeachment no STF: atores, argumentos e resultados}

O processo de impeachment foi solicitado por cidadãos em $1^{\circ}$ de setembro de 2015 , tendo seu pedido aditado em 17 de setembro. Uma semana após, no dia 24 de setembro, o Presidente da Câmara dos Deputados lê em sessão plenária a decisão sobre questão de ordem (QO 105/2015), estabelecendo o trâmite para processo de impeachment da Presidente da República. Como já mencionado, o procedimento de impeachment está regulado pela Lei 1.079/50, anterior à Constituição e, por isso, deficiente e insuficiente em muitos aspectos.

Deputados da base aliada do governo impetram dois mandados de segurança (MS 33.837 e MS 33.838) ao Supremo Tribunal Federal solicitando a suspensão da referida questão de ordem, por violação dos direitos de minorias no debate parlamentar. Os pedidos liminares foram deferidos pelos ministros Teori Zavascki e Rosa Weber, suspendendo a definição do trâmite do impeachment. Após essas decisões, o Presidente da Câmara dos Deputados anula sua própria decisão.

Em 2 de dezembro de 2015, o Presidente da Câmara dos Deputados autoriza o processamento do pedido de impeachment. Em 3 de dezembro é protocolada uma arguição de descumprimento de preceito fundamental (ADPF 378) contestando uma série de dispositivos da Lei 1.079/50 sobre o rito do impeachment. O ministro Edson Fachin suspende o trâmite do impeachment (08/12/2015) até análise do caso pelo plenário do tribunal, em 17 de dezembro de 2017. A ação foi julgada procedente parcialmente para determinar que a votação nas comissões especiais e no plenário deveriam ser abertas, vedando o voto secreto; que os membros das comissões deveriam ser escolhidos pelos partidos políticos ${ }^{21}$ e que o afastamento provisório da

20 Este artigo é submetido em meio a divulgação de uma série de conversas entre Sérgio Moro, à época responsável por conduzir a Operação Lava Jato na primeira instância e o Ministério Público Federal, com indícios de motivação política na condução da Operação Lava Jato. Mesmo antes disso, já era possível perceber esta coordenação de ações, como sustenta este artigo.

21 Havia uma discussão sobre a possibilidade de composição das comissões especiais via candidaturas avulsas, ou seja, independentes da indicação partidária. O STF considerou que a Constituição exige a representação proporcional dos partidos nas Comissões, o que 
Presidente só poderia ocorrer após o recebimento da denúncia pelo Senado Federal, enquanto uma etapa autônoma ${ }^{22}$, além de revalidar as regras aplicadas no impeachment de Fernando Collor para o processo de Dilma Rousseff ${ }^{23}$.

Essa decisão acabou por marcar a principal atuação do Supremo Tribunal Federal nos processos relativos ao impeachment, dando o tom geral de que o tribunal deveria apenas se manifestar quanto às regras procedimentais e observância do direito de defesa, sem se imiscuir ou controlar o mérito da acusação ou a pertinência da imputação de crime de responsabilidade, o que fica representado no seguinte trecho do acórdão:

"Nesse passo, cumpre avançar no sentido de fixar, em resumo, o seguinte posicionamento que aqui se propõe: não cabe ao STF editar normatização sobre a matéria; sob o pálio da autocontenção, é apenas de filtragem constitucional que aqui se cogita, isto é, incidência plena da Constituição e exame da Lei 1.079/50 à luz de princípios e regras constitucionais hoje vigentes.

A partir dessa oração-síntese, impende expor quantum satis a respectiva base argumentativa, como segue: É certo que não se pode sucumbir a argumentos puramente formalistas que impeçam a tutela do direito constitucional material em jogo sob a alegação de supostos vazios normativos. Bem por isso, cabe a este Supremo Tribunal Federal julgar a recepção do arcabouço normativo processual infraconstitucional da Lei 1.079/1950 e fazer a sua leitura à luz da Constituição de modo a permitir que, mediante processo hígido e constitucionalmente adequado, possa-se buscar a tutela do direito material.

É preciso, todavia, ressaltar: não cabe ao STF editar normatização sobre a matéria. E nem de longe se propõe edição normativa. Ao contrário, sob o pálio da autocontenção, é apenas de filtragem constitucional que aqui se cogita, isto é, incidência plena da Constituição e exame da Lei 1.079/50 à luz de princípios e regras constitucionais hoje vigentes". (STF, ADPF 347, acórdão p. 63-64, 17/12/2015, grifos originais).

A partir desta decisão o tribunal assentou que não faria o controle de constitucionalidade do impeachment em seu mérito, abstendo-se de analisar as condições constitucionais para a definição de crime de responsabilidade, deixando a caracterização, ou não, do crime a critérios única e exclusivamente políticos.

Isso faz com que o impeachment, no Brasil, seja deflagrado e conduzido exclusivamente pelas casas legislativas, sem controle de pertinência do crime de responsabilidade pelo Judiciário, tornando o chefe do Executivo nacional refém do apoio parlamentar. Se no sistema do presidencialismo de coalizão esse apoio era importante para garantir a governabilidade e a aprovação de projetos, com o desenho institucional do impeachment o Legislativo passa a dispor não só do poder de veto, mas do poder sobre o mandato eleitoral do Executivo. Atrelar

vedaria a possibilidade de candidaturas avulsas, já que a composição das comissões especiais deveria ser por membros representantes dos partidos políticos.

22 A Lei 1.079/50 previa o afastamento após a votação na Câmara dos Deputados e a Constituição estabelece o afastamento após o recebimento da denúncia pelo Senado.

23 O impeachment de Fernando Collor foi realizado pela Lei 1.079/50 e com suas idiossincrasias frente à Constituição de 1988. Por isso, naquela oportunidade, houve um acerto entre Senado, Câmara dos Deputados e Supremo Tribunal Federal para a definição do rito de processamento do impeachment. 
a continuidade de um mandato presidencial apenas a existência, ou não de apoio parlamentar é um desvirtuamento do modelo democrático consensual.

Dessa decisão são opostos embargos de declaração e o Presidente da Câmara dos deputados suspende o processo de impeachment até março de 2016, quando os embargos são julgados, corroborando a decisão em plenário. Com o seguimento do processo de impeachment, é instaurada a Comissão Especial, deliberado parecer sobre a denúncia de crime de responsabilidade e encaminhado para votação em plenário. As ações mais significativas interpostas nesse momento questionaram a inclusão de novas informações da denúncia ${ }^{24}$, a ordem de votação dos deputados em plenário ${ }^{25}$, e a ausência de justa causa para o crime de responsabilidade ${ }^{26}$. Neste último ponto, o tribunal se vale da decisão tomada anteriormente na ADPF 378, onde caberia apenas à Câmara dos Deputados o juízo de admissibilidade e Senado seu julgamento, afastando qualquer tipo de controle de mérito dos crimes de responsabilidade.

A admissibilidade da denúncia do impeachment é votada em 17 de abril de 2016, com o consequente encaminhamento do processo ao Senado Federal. O espetáculo protagonizado pelos deputados federais, que usaram bandeiras, papéis picados e homenagens, que foram de menções a familiares até torturadores ${ }^{27}$, ocupou os principais editoriais dos jornas brasileiros, consideravelmente surpresos com o que se chamou de "baixo nível” da Câmara dos Deputados. O rito de votação em plenário, especificamente a possibilidade de orientação de bancada pelos líderes, foi questionado e sumariamente negado ${ }^{28}$.

Eventuais desvios de finalidade do Presidente da Câmara dos Deputados são questionados pela defesa da Presidente da República no MS 34.193, negado pelo Ministro Teori Zavascki, que reafirma o papel de garantidor do devido processo legal, sem entra no mérito sobre

24 MS 34.130 “(...)Tratando-se de mera condição de procedibilidade para a instauração do processo de Impeachment, inexiste fumus boni iuris quanto às alegações de ofensa à ampla defesa e ao contraditório, consubstanciadas na ausência de notificação da denunciada sobre a realização de esclarecimentos acerca da denúncia e posterior indeferimento de pedido de reabertura de prazo para a manifestação da defesa, juntada de documento estranho ao objeto da denúncia e ausência de manifestação do Procurador da impetrante na sessão de leitura do relatório na Comissão Especial. Isso porque, nessa fase ainda não há acusado ou litigante (...)”. No mesmo sentido, MS 34.090.

25 ADI 5498 e MS 34.127 e MS 34.128. Ementa: CONSTITUCIONAL. VOTAÇÃO, PELO PLENÁRIO DA CÂMARA DOS DEPUTADOS, DE PARECER DA COMISSÃO ESPECIAL SOBRE ABERTURA DE PROCESSO DE IMPEACHMENT CONTRA PRESIDENTE DA REPÚBLICA. FIXAÇÃO, PELO PRESIDENTE DA CASA, DE ORDEM ALEGADAMENTE DISCREPANTE DOS ARTS. $187, \S 4^{\circ}$, E $218, \S 8^{\circ}$, DO REGIMENTO INTERNO. MODELO DE VOTAÇÃO ALTERNADA, DO NORTE PARA O SUL. PLURALIDADE DE INTERPRETAÇÕES POSSÍVEIS. AUSÊNCIA DE RELEVÂNCIA CONSTITUCIONAL. MEDIDA CAUTELAR INDEFERIDA. 1. A adoção, pelo Presidente da Câmara dos Deputados, de ordem de votação que prestigia um modelo específico de alternância no pronunciamento de parlamentares de diferentes Estados, com observância do sentido de Norte para Sul, é uma das interpretações possíveis do RICD, e não se mostra diretamente afrontosa a qualquer parâmetro da Constituição Federal. 2. Medida cautelar indeferida, por ausência de relevância dos argumentos deduzidos na inicial.

26 MS 34.131: “(...)A Câmara examina se a peça acusatória preenche as condições para ser deliberada pelo Senado Federal. É por ocasião do processamento e do julgamento da denúncia que o Senado Federal deliberará sobre a adequada qualificação jurídica dos fatos narrados. Tal juízo, como consignado no voto vencedor no âmbito ADPF 378, compete exclusivamente ao Senado Federal, de modo que eventual indicação de norma em tese não recepcionada não prejudica a validade do relatório apresentado na Comissão Especial da Câmara dos Deputados”. No mesmo sentido o MS 34.133.

27 Deputados federais, no momento de declararem seus votos sobre o impeachment, fizeram homenagens a familiares, a financiadores e até a torturadores, como o fez o deputado Jair Bolsonaro à Brilhante Ustra, torturador de Dilma Rousseff.

28 MS 34.181. 
crime de responsabilidade, além de apontar a dificuldade de se analisar desvio de finalidade pela via do mandado de segurança:

“ (...) Submete-se a exame do Supremo Tribunal Federal questão relacionada a processo por crime de responsabilidade da Presidente da República (impeachment), que, como se sabe, não é da competência do Poder Judiciário, mas do Poder Legislativo (art. 86 da CF). Sendo assim, não há base constitucional para qualquer intervenção do Poder Judiciário que, direta ou indiretamente, importe juízo de mérito sobre a ocorrência ou não dos fatos ou sobre a procedência ou não da acusação. O juiz constitucional dessa matéria é o Senado Federal, que, previamente autorizado pela Câmara dos Deputados, assume o papel de tribunal de instância definitiva, cuja decisão de mérito é insuscetível de reexame, mesmo pelo Supremo Tribunal Federal. Admitir-se a possibilidade de controle judicial do mérito da deliberação do Legislativo pelo Poder Judiciário significaria transformar em letra morta o art. 86 da Constituição Federal, que atribui, não ao Supremo, mas ao Senado Federal, autorizado pela Câmara dos Deputados, a competência para julgar o Presidente da República (...) algumas de suas investidas possivelmente questionáveis já foram neutralizadas por deliberações deste Supremo Tribunal Federal, que, nas vezes em que instado a atuar, garantiu fosse observada a cláusula constitucional do devido processo legal. Por outro lado, e por absolutamente relevante, é preciso considerar que os atos do Presidente da Câmara, inclusive o de recebimento da denúncia contra a Presidente da República, foram subsequentemente referendados em diversas instâncias da Câmara dos Deputados, com votações de acolhimento numericamente expressivas, o que qualifica - e muito - a presunção de legitimidade do ato final de autorização de instauração do processo de impeachment, que não é de competência solitária do Presidente daquela Casa Legislativa, mas do seu Plenário”. (STF, MS 34.193)

Com a admissibilidade da denúncia pelo Senado Federal, a Presidente foi afastada de suas funções e o Presidente do Supremo Tribunal Federal assumiu a presidência do Senado Federal para coordenação dos trabalhos do impeachment e resolução dos pedidos e recursos da acusação e da defesa, o que fez diminuir drasticamente a quantidade de recursos enviados ao Supremo Tribunal Federal.

A ação mais significativa após o afastamento de Dilma Rousseff é proposta por sua defesa, questionando especificamente a necessidade de tipicidade dos crimes de responsabilidade e sua ausência no caso. Liminar e monocraticamente, o mandado de segurança é denegado, com o argumento que a definição dos crimes é essencialmente política e, portanto, não estaria sujeita às mesmas exigências de tipificação do direito penal.

“(...) A tipificação de crimes de responsabilidade não está submetida aos mesmos rigores encontrados no domínio do direito penal. Desde que o núcleo central do tipo permita a imputação subjetiva de uma determinada conduta infracional, admite-se que os "tipos de responsabilidade" trabalhem com elementos descritivos mais abertos, incluindo o recurso a condutas equiparadas. (...)

Mais uma vez é necessário frisar que, pelo extrato essencialmente político dos crimes de responsabilidade, a projeção atentatória à Constituição Federal, exigida pelo art. 85, caput, não se depreenderá, no mais das vezes, do ato unitariamente imputado ao acusado, mas da desenvoltura negativa que ele adquire no contexto de governança global da Administração Pública" (STF, MS 34.371). 
De outra parte, a maior polêmica jurídica envolvendo o julgamento do impeachment no Senado se deu com a cisão das penas de perda de mandato e perda de direitos políticos, condenando-a apenas à primeira. Uma série de mandados de segurança foram impetrados pela oposição ao Supremo Tribunal Federal, mas foram abandonados quando ficou claro que vencer essas ações significaria anular a sessão de votação onde Dilma saiu condenada, ou seja, a oposição vencer seria também dar uma vitória a Dilma ${ }^{29}$.

Assim, de forma geral, as ações judiciais propostas no Supremo Tribunal Federal questionaram de forma bastante ampla o processo de impeachment: seu enquadramento legal, a ausência de tipicidade específica, os requisitos da denúncia, o desvio de finalidade do Presidente da Câmara dos Deputados, a constitucionalidade do procedimento e do próprio crime de responsabilidade, a penalidade aplicada. Mesmo que os questionamentos tenham sido amplos, o Supremo Tribunal Federal se absteve em decidir sobre eles, restringindo seu próprio papel, limitando-se a regular o devido processo legal, em sentido estrito, do impeachment, ou seja, os prazos, os atos e o rito, decididos na ADPF 378.

Abaixo estão relacionadas as principais ações judiciais sobre impeachment de Dilma Rousseff julgadas pelo Supremo Tribunal Federal, organizadas em quadro que permite visualizar os principais atores envolvidos, o objeto da ação e o seu resultado ${ }^{30}$.

\begin{tabular}{|c|c|c|c|c|c|c|c|c|}
\hline Tipo & $\mathbf{N}^{\circ}$ & Reqte & Requerido & Relator & Decisão & Órgão & Posição & Teor da decisão \\
\hline MS & 33837 & $\begin{array}{l}\text { Wadih Damous Filho } \\
\text { (Deputado PT) }\end{array}$ & $\begin{array}{l}\text { Presidente Câmara } \\
\text { dos Deputados }\end{array}$ & $\begin{array}{c}\text { Teori } \\
\text { Zavascki }\end{array}$ & Deferido & Ministro & Governo & $\begin{array}{l}\text { Suspende QO 105/2015 } \\
\text { sobre rito do impeachment }\end{array}$ \\
\hline MS & 33838 & $\begin{array}{l}\text { Rubens Pereira e } \\
\text { Silva Jr (Deputado } \\
\text { PC do B) }\end{array}$ & $\begin{array}{l}\text { Presidente Câmara } \\
\text { dos Deputados }\end{array}$ & $\begin{array}{l}\text { Rosa } \\
\text { Weber }\end{array}$ & Deferido & Ministro & Governo & $\begin{array}{l}\text { Suspende QO 105/2015 } \\
\text { sobre rito do impeachment }\end{array}$ \\
\hline $\mathrm{ADPF}$ & 378 & $\mathrm{PC}$ do $\mathrm{B}$ & $\begin{array}{l}\text { Presidente e } \\
\text { Congresso } \\
\text { Nacional }\end{array}$ & $\begin{array}{l}\text { Edson } \\
\text { Fachin }\end{array}$ & $\begin{array}{l}\text { Deferido, } \\
\text { parcial }\end{array}$ & Plenário & Governo & $\begin{array}{l}\text { Suspende o trâmite do } \\
\text { impeachment e estabelece } \\
\text { o seu rito definitivo }\end{array}$ \\
\hline MS & 34130 & $\begin{array}{l}\text { Presidente da } \\
\text { República }\end{array}$ & $\begin{array}{l}\text { Presidente Câmara } \\
\text { dos Deputados }\end{array}$ & $\begin{array}{l}\text { Edson } \\
\text { Fachin }\end{array}$ & Indeferido & Plenário & Governo & $\begin{array}{l}\text { Não limita analise da CE } \\
\text { a atos da denúncia e não } \\
\text { devolve prazo de defesa }\end{array}$ \\
\hline MS & 34127 & $\begin{array}{l}\text { Weverton Marques } \\
\text { (Deputado PDT) }\end{array}$ & $\begin{array}{l}\text { Presidente Câmara } \\
\text { dos Deputados }\end{array}$ & $\begin{array}{l}\text { Roberto } \\
\text { Barroso }\end{array}$ & Indeferido & Plenário & Governo & $\begin{array}{c}\text { Não considera questão } \\
\text { constitucional a ordem } \\
\text { de votação dos } \\
\text { deputados em plenário }\end{array}$ \\
\hline MS & 34128 & $\begin{array}{l}\text { Rubens Pereita e } \\
\text { Silva Jr. (Deputado } \\
\text { PC do B) }\end{array}$ & $\begin{array}{l}\text { Presidente Câmara } \\
\text { dos Deputados }\end{array}$ & $\begin{array}{l}\text { Roberto } \\
\text { Barroso }\end{array}$ & Indeferido & Plenário & Governo & $\begin{array}{c}\text { Não considera questão } \\
\text { constitucional a ordem de } \\
\text { votação dos deputados em } \\
\text { plenário }\end{array}$ \\
\hline
\end{tabular}

29 Nesse sentido: MS 34.378; MS 34.379; MS 34.384; MS 34.385; MS 34.386; MS 34.394.

30 Este quadro foi realizado a partir de pesquisa sobre as ações judiciais propostas no Supremo Tribunal Federal durante o processo de impeachment (de outubro de 2015 a setembro de 2016). Foram selecionadas as ações que casaram algum tipo de resposta do tribunal, seja monocraticamente (na tabela o equivalente a ministro em órgão decisório) ou em plenário, deixando de fora as ações que foram propostas por parte ilegítimas ou que careciam de preparo. 


\begin{tabular}{|c|c|c|c|c|c|c|c|c|}
\hline MS & 34131 & $\begin{array}{l}\text { Paulo Teixeira } \\
\text { (Deputado PT) }\end{array}$ & $\begin{array}{c}\text { Presidente da } \\
\text { Comissão Especial } \\
\text { - CD }\end{array}$ & $\begin{array}{l}\text { Edson } \\
\text { Fachin }\end{array}$ & Indeferido & Plenário & Governo & $\begin{array}{l}\text { Considera que o STF não } \\
\text { deve analisar justa causa do } \\
\text { crime de responsabilidade }\end{array}$ \\
\hline MS & 34133 & $\begin{array}{l}\text { Telmario Mota } \\
\text { (Deputado PT) }\end{array}$ & $\begin{array}{l}\text { Presidente Câmara } \\
\text { dos Deputados }\end{array}$ & $\begin{array}{l}\text { Edson } \\
\text { Fachin }\end{array}$ & Indeferido & Ministro & Governo & $\begin{array}{l}\text { Considera que o STF não } \\
\text { deve analisar justa causa do } \\
\text { crime de responsabilidade }\end{array}$ \\
\hline ADPF & 397 & PDT & $\begin{array}{l}\text { Presidente Câmara } \\
\text { dos deputados }\end{array}$ & $\begin{array}{c}\text { Marco } \\
\text { Aurelio }\end{array}$ & Indeferido & Ministro & Governo & $\begin{array}{l}\text { Não considera passível de } \\
\text { controle via ADPF o desvio } \\
\text { de finalidade do Presidente } \\
\text { da Câmara dos Deputados }\end{array}$ \\
\hline ADI & 5498 & $\mathrm{PC}$ do $\mathrm{B}$ & $\begin{array}{l}\text { Câmara dos } \\
\text { Deputados }\end{array}$ & $\begin{array}{c}\text { Marco } \\
\text { Aurelio }\end{array}$ & Indeferido & Plenário & Governo & $\begin{array}{l}\text { Não considera questão } \\
\text { constitucional a ordem de } \\
\text { votação dos deputados } \\
\text { em plenário }\end{array}$ \\
\hline MS & 34181 & $\begin{array}{l}\text { Paulo Teixeira } \\
\text { (Deputado PT) }\end{array}$ & $\begin{array}{l}\text { Presidente Câmara } \\
\text { dos Deputados }\end{array}$ & $\begin{array}{l}\text { Luiz } \\
\text { Fux }\end{array}$ & Indeferido & Ministro & Governo & $\begin{array}{l}\text { Não considera possível o } \\
\text { questionamento sobre } \\
\text { encaminhamento de líderes } \\
\text { na votação do plenário }\end{array}$ \\
\hline MS & 34193 & $\begin{array}{l}\text { Presidente da } \\
\text { República }\end{array}$ & $\begin{array}{l}\text { Presidente Câmara } \\
\text { dos Deputados }\end{array}$ & $\begin{array}{c}\text { Teori } \\
\text { Zavascki }\end{array}$ & Indeferido & Ministro & Governo & $\begin{array}{c}\text { Não aceita a tese de desvio } \\
\text { de finalidade }\end{array}$ \\
\hline MS & 34371 & $\begin{array}{l}\text { Presidente da } \\
\text { República }\end{array}$ & $\begin{array}{l}\text { Presidente STF } \\
\text { enquanto Presidente } \\
\text { do Senado }\end{array}$ & $\begin{array}{c}\text { Teori } \\
\text { Zavascki }\end{array}$ & Indeferido & Ministro & Governo & $\begin{array}{l}\text { Não aceita controle da tipi- } \\
\text { cidade do crime de } \\
\text { responsabilidade }\end{array}$ \\
\hline MS & 34378 & PSL & $\begin{array}{c}\text { Presidente STF e } \\
\text { nquanto Presidente } \\
\text { do Senado }\end{array}$ & $\begin{array}{l}\text { Rosa } \\
\text { Weber }\end{array}$ & Indeferido & Ministro & Oposição & $\begin{array}{l}\text { Mantém separação de penas } \\
\text { no julgamento de } \\
\text { impeachment }\end{array}$ \\
\hline MS & 34379 & $\begin{array}{l}\text { Álvaro Dias } \\
\text { (Senador PV) }\end{array}$ & $\begin{array}{c}\text { Presidente STF } \\
\text { enquanto Presidente } \\
\text { do Senado }\end{array}$ & $\begin{array}{l}\text { Rosa } \\
\text { Weber }\end{array}$ & Indeferido & Ministro & Oposição & $\begin{array}{l}\text { Mantém separação de penas } \\
\text { no julgamento de impea- } \\
\text { chment }\end{array}$ \\
\hline MS & 34384 & $\begin{array}{l}\text { José Medeiros } \\
\text { (Senador PSD) }\end{array}$ & $\begin{array}{c}\text { Presidente STF } \\
\text { enquanto Presidente } \\
\text { do Senado }\end{array}$ & $\begin{array}{l}\text { Rosa } \\
\text { Weber }\end{array}$ & Indeferido & Ministro & Oposição & $\begin{array}{l}\text { Mantém separação de penas } \\
\text { no julgamento de } \\
\text { impeachment }\end{array}$ \\
\hline MS & 34385 & $\begin{array}{l}\text { Expedito Netto } \\
\text { (Deputado SD) }\end{array}$ & $\begin{array}{c}\text { Presidente STF } \\
\text { enquanto Presidente } \\
\text { do Senado }\end{array}$ & $\begin{array}{l}\text { Rosa } \\
\text { Weber }\end{array}$ & Indeferido & Ministro & Oposição & $\begin{array}{l}\text { Mantém separação de penas } \\
\text { no julgamento de } \\
\text { impeachment }\end{array}$ \\
\hline MS & 34386 & $\begin{array}{l}\text { Expedito Netto } \\
\text { (Deputado SD) }\end{array}$ & $\begin{array}{l}\text { Presidente STF } \\
\text { enquanto Presidente } \\
\text { do Senado }\end{array}$ & $\begin{array}{l}\text { Rosa } \\
\text { Weber }\end{array}$ & Indeferido & Ministro & Oposição & $\begin{array}{l}\text { Mantém separação de penas } \\
\text { no julgamento de } \\
\text { impeachment }\end{array}$ \\
\hline MS & 34394 & $\begin{array}{l}\text { PSDB; DEM; PPS; } \\
\text { PMDB }\end{array}$ & $\begin{array}{c}\text { Presidente STF } \\
\text { enquanto Presidente } \\
\text { do Senado }\end{array}$ & $\begin{array}{l}\text { Rosa } \\
\text { Weber }\end{array}$ & Indeferido & Ministro & Oposição & $\begin{array}{l}\text { Mantém separação de penas } \\
\text { no julgamento de } \\
\text { impeachment }\end{array}$ \\
\hline
\end{tabular}

Quadro 1. Ações sobre o processo de impeachment no Supremo Tribunal Federal

Em toda provocação para que se manifestasse sobre o mérito, sobre a constitucionalidade do crime de responsabilidade imputado e do impeachment, o tribunal se absteve em favor do Congresso Nacional, a quem ficou reconhecida a competência não só de processamento e julgamento, mas de definição de quais atos podem ser crimes de responsabilidade passíveis de impeachment, sem qualquer forma de controle judicial. 
Essa autocontenção do tribunal, presente nas ações judicias que questionaram o impeachment, não se sustenta se incluirmos na análise os processos judiciais relativos à Operação Lava Jato, julgados no mesmo período e envolvendo, muitas das vezes, os mesmos atores do impeachment. É o que se passa a descrever no próximo tópico.

\subsection{Os processos judiciais relativos à Operação Lava Jato: atores, argumentos}

\section{e resultados}

A chamada Operação Lava Jato foi levada ao Supremo Tribunal Federal pelo Procurador Geral da República em março de 2015, quando solicitou a abertura inquéritos policiais ${ }^{31}$ para investigar deputados, senadores e ministros de Estado $^{32}$.

De março a outubro de 2015 não houve nenhuma decisão significativa do tribunal, ocupado então com recursos e com a separação de ações que ficariam sob a jurisdição do Supremo ou que seriam encaminhadas para outras instâncias judiciais ${ }^{33}$.

A partir do desenrolar do processo de impeachment, o Supremo Tribunal Federal adota medidas excepcionais relacionadas à Lava Jato que, quer pelos atores envolvidos, momento ou teor, tiveram o condão de influenciar momentos determinantes do procedimento que culminou com o afastamento de Dilma Rousseff.

Em novembro, pela primeira vez após a promulgação da Constituição de 1988, um senador da República - no caso, Delcídio do Amaral, líder do governo no Senado Federal - é preso por ordem do Supremo Tribunal Federal por tentativas de obstrução às investigações da Operação Lava Jato.

No contexto anterior a sua prisão, foram divulgados áudios gravados de uma conversa de Delcídio em 4 de novembro de 2015, onde prometia ao filho de Nestor Cerveró (um dos diretores da Petrobrás presos na Operação Lava Jato) meios para acesso a ministros do Supremo e arranjos para uma eventual fuga do país ${ }^{34}$.

Essa gravação foi amplamente divulgada pela mídia e gerou o pedido de prisão provisória feito pelo Procurador Geral da República na ação cautelar AC 4039, deferida liminarmente pelo ministro Teori Zavascki e depois corroborada em plenário em 25 de novembro de 2015, pois

“(...) a conversa gravada revela, ademais, iniciativas concretas e compromissos determinados do Senador Delcídio do Amaral (...) para, mediante injunção espúria junto a Ministros do Supremo Tribunal Federal, obter liberdade para Nestor Cerveró (...) e, em seguida, auxiliar àquele

\footnotetext{
31 O Procurador Geral da República pediu a abertura de 28 inquéritos policiais contra 54 autoridades públicas. Destes, 21 foram autorizados e o restante foi arquivado ou remetido a outras instâncias judiciais. As informações estão disponibilizadas pelo próprio tribunal, em nota organizada por sua assessoria de imprensa (06/03/2015) em http://www.stf.jus.br/portal/cms/verNoticiaDetalhe. asp?idConteudo=286808, visto em 19 de março de 2017.

32 A Constituição Federal de 1988 estabelece foro por prerrogativa de função para distintas autoridades públicas. No Supremo Tribunal Federal são julgadas, originariamente, as ações penais e investigações conduzidas contra deputados federais, senadores, ministros de Estado, Presidente da República e seu vice, além dos próprios ministros do Supremo Tribuna Federal.

33 O Supremo Tribunal Federal decidiu que analisaria todas as informações da Operação Lava Jato que envolvessem autoridades públicas com foro privilegiado e pessoas sem foro especial, para então definir, caso a caso, onde ficam os casos de pessoas sem foro. Na ação penal 470, conhecida como mensalão, o Supremo preferiu manter todas as ações consigo, mesmo de investigados e réus sem foro.

34 O teor da conversa traz elementos comparáveis a fugas cinematográficas, incluindo o uso de um veleiro que cruzaria o oceano pacífico saindo da Venezuela.
} 
a deixar o País, ainda que em burla a dispositivo pessoal de vigilância eletrônica". (STF, AC 4039)

A Constituição estabelece uma série de condições para que seja possível a prisão de um senador da República, como a flagrância de um crime inafiançável e a posterior validação da medida pelo órgão Legislativo35, tornando-a medida excepcionalíssima.

Por este motivo, a prisão de Delcídio do Amaral teve sua constitucionalidade questionada, já que não haveria a gravidade exigida constitucionalmente, sobretudo quando não haveria nenhum ato que mostrasse a intenção de concretização de influência junto a ministros do Supremo ou mesmo de arranjos para fuga. Dilma perde seu principal líder no Senado durante o debate sobre impeachment e Delcídio é solto em pouco menos de 3 meses, em fevereiro de 2016.

Em 2 de março de 2016, o Supremo torna réu o Presidente da Câmara dos Deputados Eduardo Cunha em decisão no inquérito policial IP 3893, acusado de receber valores provenientes de desvio de recursos da Petrobras, caracterizando os crimes de corrupção passiva e lavagem de dinheiro. Eduardo Cunha tenta, ao mesmo tempo, preservar seu mandato e impedir votações na Comissão de Ética da Câmara dos Deputados. Pressionado, usa seu papel no impeachment como barganha.

Ainda em março de 2016, duas decisões judiciais tomadas no âmbito da Operação Lava Jato criam uma enorme instabilidade no governo de Dilma Rousseff.

No dia 16, o juiz que conduz os casos da Operação Lava Jato em primeira instância para pessoas sem foro privilegiado, Sergio Moro, divulga áudios de interceptações telefônicas onde a Presidente Dilma Rousseff avisava Lula, indicado a ministro da Casa Civil no mesmo dia, que lhe enviaria o termo de posse para usar em caso de necessidade.

A divulgação, embora ilegal36, é usada pelo ministro Gilmar Mendes para suspender a posse de Lula como ministro, em decisão liminar tomada no mandado de segurança MS 34.070, em 18 de março de 2016:

“(...) Aplicando essas noções ao caso em tela, tem-se que a Presidente da República praticou conduta que, a priori, estaria em conformidade com a atribuição que lhe confere o art. 84, inciso I, da Constituição - nomear Ministros de Estado. Mas, ao fazê-lo, produziu resultado concreto de todo incompatível com a ordem constitucional em vigor: conferir ao investigado foro no Supremo Tribunal Federal. (...)

É muito claro o tumulto causado ao progresso das investigações, pela mudança de foro. E 'autoevidente' que o deslocamento da competência é forma de obstrução ao progresso das medidas judiciais.

Não se nega que as investigações e as medidas judiciais poderiam ser retomadas perante o STF. Mas a retomada, no entanto, não seria sem atraso e desassossego. O tempo de trâmite para o STF, análise pela PGR, seguida da análise pelo relator e, eventualmente, pela respectiva Turma, poderia ser fatal para a colheita de provas, além de adiar medidas cautelares".

35 Constituição Federal de 1988, art. 53. "Os Deputados e Senadores são invioláveis, civil e penalmente, por quaisquer de suas opiniões, palavras e votos. ... § $2^{\circ}$ Desde a expedição do diploma, os membros do Congresso Nacional não poderão ser presos, salvo em flagrante de crime inafiançável. Nesse caso, os autos serão remetidos dentro de vinte e quatro horas à Casa respectiva, para que, pelo voto da maioria de seus membros, resolva sobre a prisão".

36 A Lei 9296/96 impõe sigilo às interceptações telefônicas. Ademais, não havia ordem judicial válida no momento da interceptação, captada em violação ao direito constitucional de sigilo das comunicações, sem mencionar a incompetência do juízo de primeira instância, em razão de foro especial da Presidente, para praticar qualquer ato processual no caso, como a retirada do sigilo. 
A decisão liminar do ministro Gilmar Mendes é bastante criticada pela sua excepcionalidade ${ }^{37}$, já que contrariou a jurisprudência do tribunal quanto à impossibilidade de partidos políticos, mediante mandado de segurança coletivo, questionarem atos do Executivo, bem como pela tese de desvio de finalidade em obstrução da justiça e pelo uso de prova ilícita, já que as gravações dos áudios foram obtidas de forma ilegal ${ }^{38}$. Mesmo assim, outras ações contra a decisão de Gilmar Mendes não foram aceitas, por não caracterizarem recurso ${ }^{39} \mathrm{e}$ a liminar não é enviada a plenário para julgamento até que perdeu seu objeto, após o impeachment ter se concretizado.

Por fim, após o processo de impeachment ser votado em plenário na Câmara dos Deputados e enviado ao Senado Federal, é proposta uma ação cautelar AC 4070 pedindo a suspensão do exercício do mandato por Eduardo Cunha, com o seu consequentemente afastamento da Presidência da Câmara dos Deputados. A medida é deferida em 4 de maio de 2016, com o argumento de que Eduardo Cunha estava usando as prerrogativas de deputado em benefício próprio e abusava de seu poder para evitar ser responsabilizado.

\begin{abstract}
“(...) 20. Os elementos fáticos e jurídicos aqui considerados denunciam que a permanência do requerido, o Deputado Federal Eduardo Cunha, no livre exercício de seu mandato parlamentar e à frente da função de Presidente da Câmara dos Deputados, além de representar risco para as investigações penais sediadas neste Supremo Tribunal Federal, é um pejorativo que conspira contra a própria dignidade da instituição por ele liderada. Nada, absolutamente nada, se pode extrair da Constituição que possa, minimamente, justificar a sua permanência no exercício dessas elevadas funções públicas. Pelo contrário, o que se extrai de um
\end{abstract}

37 Após essa decisão do ministro Gilmar Mendes, o Supremo foi instado a se pronunciar outras duas vezes em igual teor. No mandado de segurança coletivo MS 34196, o ministro Luis Roberto Barroso indicou que não seria possível o uso do mandado de segurança coletivo por partidos políticos para defesa de interesses difusos e que obstar a nomeação de ministros seria excessiva interferência do Judiciário na política: “(...) 8. A Lei no 12.016/2009 parece ter adotado limites razoáveis, compatíveis com a Constituição, para o cabimento de mandado de segurança coletivo. A restrição dessa modalidade de ação para a tutela de direitos coletivos em sentido estrito e individuais homogêneos evita que o mandado de segurança seja instrumentalizado pelos partidos políticos, transformandose em indesejável veículo de judicialização excessiva de questões governamentais e parlamentares, as quais poderiam ser facilmente enquadradas como direitos difusos da sociedade brasileira e atreladas às finalidades de qualquer agremiação política. 9. A interferência excessiva do direito e do Poder Judiciário na política, ainda que iniciada ou fomentada pela atuação dos próprios partidos políticos, pode acarretar prejuízo à separação dos poderes e, em última análise, ao próprio funcionamento da democracia. Agrega-se ao dia-a-dia político um elemento de insegurança, consistente em saber como o Judiciário se pronunciará sobre os mais variados atos praticados pelo Executivo e pelo Legislativo, inclusive aqueles eminentemente internos, como os atos de nomeação e exoneração de Ministro de Estado. (...)18. Por fim, ainda que fosse possível superar os óbices quanto ao cabimento, a pretensão do impetrante não mereceria acolhimento no mérito. A avaliação quanto à continuidade ou não das políticas em curso e sobre medidas de transição destinadas a suavizar o impacto de eventuais mudanças é de natureza primordialmente política, e deve ser feita não apenas pelo substituto constitucional da Presidência da República, mas também pelas instâncias competentes para fazer o juízo político quanto ao eventual afastamento temporário da Chefe do Poder Executivo. O princípio constitucional da segurança jurídica simplesmente não tem o alcance pretendido pela petição inicial, que, em última análise, imobilizaria completamente a atividade política. E, não custa lembrar, o VicePresidente também integra a chapa eleita pelo voto popular. 19. Além disso, o País ficaria virtualmente acéfalo se o Vice-Presidente fosse impedido de exercer as funções privativas do Presidente da República, que compreendem não apenas a nomeação e a exoneração de Ministros de Estado (inciso I do art. 84), mas todas as demais atribuições (...)". No mesmo sentido, o mandado de segurança MS 34.609, no qual o ministro Celso de Mello manteve no cargo o ministro Moreira Franco, nomeado por Temer, citado na Operação Lava Jato e denunciado por outros crimes. Nesse caso, tampouco se reconheceu a legitimidade do uso do mandado de segurança coletivo por partidos políticos para defesa de interesses difusos, bem como a existência de desvio de finalidade em nomeação de ministros.

38 A ilicitude das provas acaba sendo comprovada pelo próprio tribunal, em reclamação RCL 23.457: “(...) julgo procedente para reconhecer a violação de competência do Supremo Tribunal Federal e cassar as decisões proferidas pelo juízo da 13a Vara Federal da Subseção Judiciária de Curitiba em 16.3.2016 e 17.3.2016, nos autos do "Pedido de Quebra de Sigilo de Dados e/ou Telefônicos 5006205-98.2016.4.04.7000/PR", que determinaram o levantamento do conteúdo de conversas lá interceptadas; e (b) reconhecer a nulidade do conteúdo de conversas colhidas após a determinação judicial de interrupção das interceptações telefônicas".

39 MS 34079 e HC 133605. 
contexto constitucional sistêmico, é que o exercício do cargo, nas circunstâncias indicadas, compromete a vontade da Constituição, sobretudo a que está manifestada nos princípios de probidade e moralidade que devem governar o comportamento dos agentes políticos. (...)

21. Decide-se aqui uma situação extraordinária, excepcional e, por isso, pontual e individualizada. A sintaxe do direito nunca estará completa na solidão dos textos, nem jamais poderá ser negativada pela imprevisão dos fatos. Pelo contrário, o imponderável é que legitima os avanços civilizatórios endossados pelas mãos da justiça. Mesmo que não haja previsão específica, com assento constitucional, a respeito do afastamento, pela jurisdição criminal, de parlamentares do exercício de seu mandato, ou a imposição de afastamento do Presidente da Câmara dos Deputados quando o seu ocupante venha a ser processado criminalmente, está demonstrado que, no caso, ambas se fazem claramente devidas". (STF, AC 4070).

Essa decisão também foi dotada de alto grau de excepcionalidade - o que é assumido pelo ministro relator do caso, Teori Zavascki, já que a Constituição prevê uma série de garantias - inclusive a impossibilidade de prisão - para que um parlamentar permaneça no exercício de sua função, o que seria contrariado se, para impedir a prisão, o mandato fosse suspenso, como determinado na decisão.

Mais do que isso, o argumento acatado pelos ministros para afastar excepcionalmente Eduardo Cunha após o impeachment tramitar na Câmara dos Deputados foi rejeitado antes, quando apresentado pela defesa de Dilma Rousseff alegando que Eduardo Cunha agia com abuso de poder e desvio de finalidade na condução do impeachment, barganhando sua absolvição na Comissão de Ética em troca de aprovar o impeachment ${ }^{40}$.

Juntas, a prisão do senador Delcídio do Amaral, a suspensão da posse de Lula como ministro e o afastamento de Eduardo Cunha são decisões dotadas de algo grau de excepcionalidade e que interferiram indiretamente no curso do impeachment, ora neutralizando atores em momentos relevantes, ora permitindo que agissem.

\section{Conclusão: a interferência do STF no processo de impeachment através de decisões excepcionais na Operação Lava Jato.}

Ao analisar as decisões do Supremo Tribunal Federal no impeachment de Dilma Rousseff é possível constatar um alto grau de autocontenção dos ministros e do tribunal, afirmando que o papel a ser desempenhado se restringia apenas à garantia de devido processo legal em sentido estrito, definindo as etapas e momentos de defesa da Presidente.

Em todas as oportunidades em que foi instado a se manifestar sobre o mérito do impeachment ou o controle de constitucionalidade os crimes de responsabilidade, o tribunal se eximiu, determinando a ampla competência da Câmara dos Deputados e do Senado Federal para definir os requisitos do processo.

Essa constatação traz, por si só, uma série de questionamentos sobre os limites do

40 Ver MS 34.193, página 14. 
presidencialismo no Brasil, já que haveria um grande poder de cassação de mandato alocado no Legislativo, dependente apenas do humor das bases parlamentares, sem qualquer restrição ou exigência constitucional sobre a gravidade ou excepcionalidade dos crimes de responsabilidade.

Afinal, a definição do crime de responsabilidade e de sua gravidade dependeria apenas e tão comente do Legislativo, sem qualquer incidência de controle de constitucionalidade pelo Supremo Tribunal Federal. Isso contraria a proteção constitucional conferida aos mandatos e a próprio desenho de responsabilização de Presidente da República.

Para além disso, essa jurisprudência de autocontenção poderia dar a impressão de que o Supremo Tribunal Federal não interferiu nos rumos do impeachment. Entretanto, a análise das principais decisões relativas à Operação Lava Jato, proferidas concomitantemente ao impeachment, mostra que o tribunal operou com alto grau de excepcionalidade, interferindo abruptamente no Legislativo e no Executivo, dando o tom de gravidade dos casos. Além disso, o tribunal atuou o ora neutralizando atores relevantes - como Lula e Delcídio do Amaral - ora deixando que outros atores, comprometidos, seguissem atuando, como Eduardo Cunha.

Tudo isso foi feito, também, de forma bastante articulada com as principais etapas do processo de impeachment:

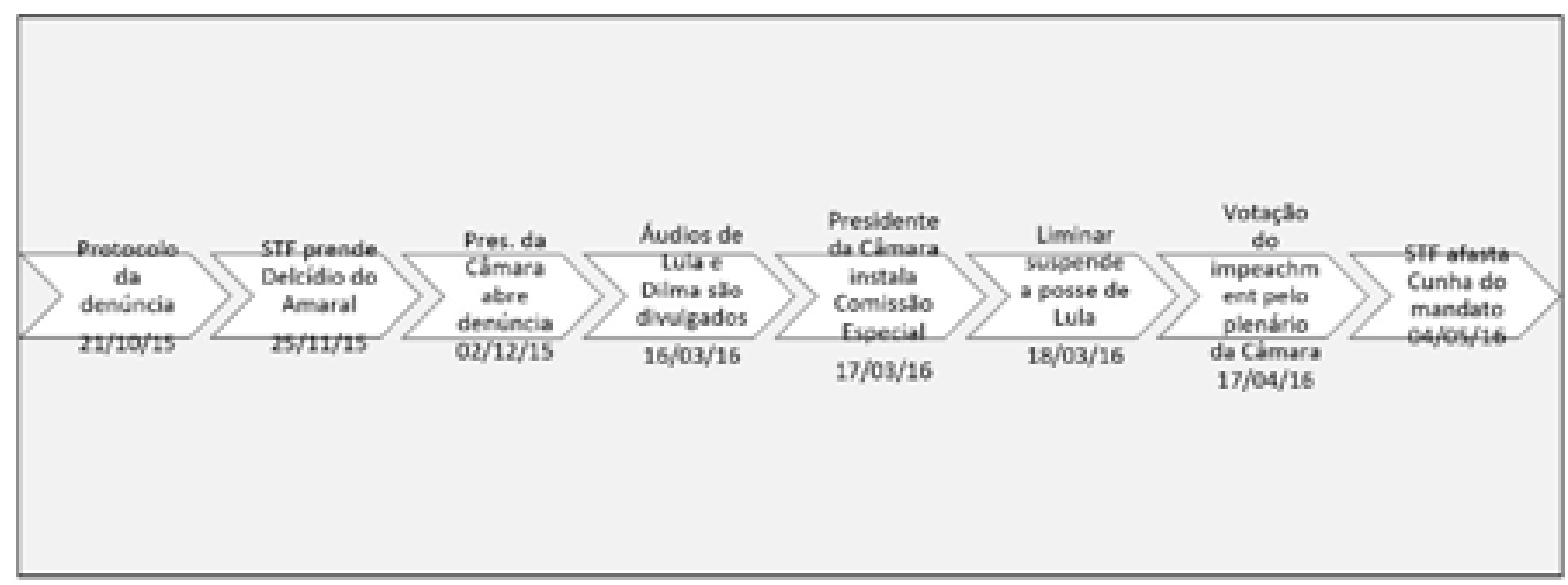

Quadro 2. Fluxo das decisões do STF na Operação Lava Jato e etapas relevantes do impeachment.

De forma geral, o impeachment de Dilma Rousseff mostra uma fragilidade dos mecanismos de proteção ao mandato eleitoral, na medida em que não foram exigidos quaisquer requisitos para a caracterização do crime de responsabilidade, o que acarreta, consequentemente, uma relação de dependência com o Legislativo não só para a adoção de políticas e implementação de um plano de governo, mas para a manutenção do mandato em si.

Quanto ao papel do Supremo Tribunal Federal, ao se eximir de promover controle de constitucionalidade do impeachment, sobretudo dos requisitos dos crimes de responsabilidade, colabora para o estabelecimento dessa relação de intensa dependência do Executivo em relação ao Legislativo, pervertendo os mecanismos constitucionais de proteção ao mandato eleitoral. 
Mais do que isso, a análise das decisões tomadas pelo Supremo Tribunal Federal, colegiadas ou individualmente, no âmbito da Operação Lava Jato, aponta para um alto grau de interferência indireta do tribunal no impeachment, sobretudo em decisões alteraram a dinâmica do jogo político nas casas legislativas e no próprio Executivo, em períodos muito próximos a etapas fundamentais do processo de cassação.

Assim, a neutralidade e autocontenção do tribunal no processo de impeachment é apenas aparente; o Supremo Tribunal Federal foi, sobretudo, um agente catalizador da crise política.

\section{Referências bibliográficas}

ABRANCHES, Sérgio. Presidencialismo de coalizão: o dilema institucional brasileiro. Dados, v. 31, n. 1, p. 5-38, 1988.

BASTOS, Celso Ribeiro. Curso de direito constitucional. São Paulo: Saraiva, 1990.

BROSSARD, Paulo. O impeachment. São Paulo: Saraiva, 1992.

DOWNS, Anthony. Uma teoria econômica da democracia. São Paulo: Edusp, 1999.

ELSTER, Jon. Ulisses liberto: estudos sobre racionalidade, pré-compromisso e restrições. São Paulo: Editora UNESP, 2009.

FIGUEIREDO, Argelina; LIMONGI, Fernando. Bases institucionais do presidencialismo de coalizão. Lua Nova, v. 44, p. 81-106, 1998.

LIMONGI, Fernando. A democracia no Brasil: presidencialismo, coalizão partidária e processo decisório. Novos estudos-CEBRAP, n. 76, p. 17-41, 2006.

TEMER, Michel. Elementos de direito constitucional. São Paulo: Malheiros, 1994.

RYDGREN, Jens. In: Annual Review of Sociology, 1/1/2007, Vol. 33, p. 241-262

STF. Supremo Tribunal Federal. Documentos diversos. www.stf.jus.br

SUNSTEIN, Cass R. Designing democracy: what constitutions do. Oxford University Press, 2001.

TSE. Tribunal Superior Eleitoral. Informações diversas. http://www.tse.jus.br/eleicoes/estatisticas/estatisticas-eleitorais-2014-resultado 
SOBRE A AUTORA:

\section{Eloísa Machado de Almeida}

Doutora em direitos humanos pela Faculdade de Direito da Universidade de São Paulo (USP) e mestre em Ciências Sociais pela Pontifícia Universidade Católica de São Paulo (PUC-SP). Possui graduação em direito pela PUC-SP. É professora da FGV DIREITO SP e coordenadora do Supremo em Pauta da FGV Direito SP.

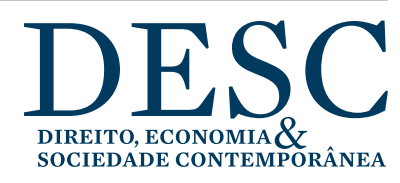

